\title{
The same old story - or not? How storytelling can support inclusive local energy policy
}

\begin{abstract}
Local energy policy agendas require commonly defined desirable future visions and collective agenda-setting to spur collaborative action. However, methods designed for multi-stakeholder engagement often do not sufficiently open up deliberative processes to all voices, and efforts to envision desired futures built from current local energy challenges are usually designed by and oriented towards specialists. With this paper, we aimed to explore how the theoretical strengths of storytelling for supporting local policy processes play out in practice. We contrast what the literature states about the potential of storytelling for solving complex challenges and facilitating collaborative processes to the lessons learnt from actually using storytelling in a set of 17 multistakeholder workshops across 17 European countries run as part of the H2020 SHAPE ENERGY project. The workshops were each designed around a tangible local energy policy challenge. We found storytelling has unique strengths in terms of enabling significant (un)learning regarding stakeholder relationships, allowing participants to step into others' perspectives, keeping hold of diversity, and the use of 'we' in stories leading to concrete future initiatives. We also note specific learnings about when these outcomes may not be achieved, for example due to fears, traditions, hierarchical structures, as well as the need for sufficient time for planning, facilitator training and stakeholder invitations. We conclude that as an innovative, playful and flexible methodology, storytelling can undoubtedly be a valuable additional tool for policymakers where there is a desire for deliberative stakeholder involvement, and appetite to tailor approaches to local contexts.
\end{abstract}

Keywords: Collaborative Decision-Making, Climate Change, Urban Agendas, Stakeholder Engagement, Collective Visions.

\section{Highlights:}

1) Novel series of 17 city workshops on local energy policy using storytelling;

2) Storytelling proved particularly effective at revealing stakeholder/power dynamics;

3) Fears (e.g. future burdens/unpopularity) can weaken a collaborative agenda setting;

4) Storytelling has unique inclusivity strengths, e.g. writing from others' viewpoints;

5) Policy outcomes included permanent platforms, strategies, rich stakeholder visions. 


\section{Introduction}

Energy policy targets are increasing in number and ambition, aimed at tackling multiple energy-related issues including climate change, energy security and fuel poverty [1-3]. While such energy targets are created at multiple levels/scales of government (international, national, regional, local), when it comes to 'on-the-ground' implementation to meet such targets, local governments (i.e. local authorities or municipalities) play a crucial role. Local governments are arguably the closest policy group to citizens, and trust in them is generally found to be higher than trust in national government [4]. Also, with their well-recognised 'brands' they are often at the forefront of bringing multi-stakeholder groups together to work locally, which is vital for crosscutting issues such as energy that require both active collaborative working [5] and consideration of local context [6]. The need to better understand and support this local policy work is, therefore, increasingly recognised. The EU's Urban Agenda aims indeed to involve urban authorities and their partners to improve the quality of life in Europe's cities, towns and suburbs.

However, efforts for supporting this specific local policy work are often unsuccessful in two essential ways. First, methods designed for multi-stakeholder engagement do not always sufficiently open up deliberative processes for those people, perspectives and voices which might not feel competent or able to participate $[7,8]$. Second, efforts to envision desired futures building from current local energy challenges, are usually designed by and oriented towards specialists, whether in energy policy or business $[9,10]$. They seldom involve a full range of stakeholders in their making. This is largely due to the technocratic record and progress of the energy sector, seen as primarily a Science, Technology, Engineering and Mathematics (STEM) field, with low trust for the capacity of broader public engagement to help to find solutions to today's challenges. This means that methods from the Social Sciences and Humanities (SSH) are still predominantly regarded as a means to mainly orient the market and encourage individuals to accept a top-down policy, technology or process [11]. Crucially, this means that multi-stakeholder working techniques (often developed from SSH) and local energy policy implementation learnings are not easily applicable in many cases [12-14].

One such technique, which this paper aims to disseminate and analyse, is storytelling. In this paper, we define a story as being a purposefully 'plotted' account (following a plot or 'story spine') of a sequence of events (which does not have to be chronological) and the principle of cause and effect [15]. Within storytelling research, the following aspects have been particularly well explored: use of storytelling in communication and persuasion, especially in healthcare contexts [16], but also organisational practices [17]; problem-framing in the media and industries [18,19]; and, more recently, participatory engagement and vision building [20]. In the last few years, storytelling has also generated significant attention in the context of energy research [21,22] indeed with a special issue in this journal [23]. Studies have dealt with stories about transitioning energy from fossil fuels to renewables, transitioning transportation, and of course, the 'story' of the current climate emergency [20]. Encouraging respondents to articulate the past in terms of stories has revealed previously undocumented phenomena in the 
private world of domestic heating [24] and the relationship between building occupants and resultant energy use in the context of adaptive comfort strategies [25].

Storytelling methods, and narrative-based work more generally, can therefore be used for a variety of purposes. Goodchild et al. (2017) for example distinguish between three, complementary types of storytelling: (1) persuasive storytelling that helps generate consensus for action; (2) learning stories [26] that draw on examples of success to avoid future mistakes; (3) personal stories collected to create oral history. Although elements of the first (particularly using collaborative storytelling to generate local policy action) and third of these were present, storytelling was primarily chosen in our project due to what it can offer in the second regard. Specifically, this meant as a valid route to learning about and thus understanding and communicating real-life (necessarily subjectively interpreted) experience [23], which after all is the context in which energy transitions must ultimately take place.

However, the local policy context has not tended to be a central feature of storytelling research [27,28]; whilst much research emphasises the promises of achieving policy impact via iterative, collaborative, or holistic approaches [29-31] to date there is very little research on the application of storytelling in any local policy contexts. Questions, therefore, remain unanswered, including how meaningful the actual application of storytelling in local energy policy contexts can be, and crucially how the use of storytelling in practice may differ from what is said in theory regarding for example learning and unlearning processes, the creation of empathy, conflictsolving, the inclusion of diverse perspectives and fostering new collaborations and actions.

To fill this gap, we draw on a very large-scale storytelling roll-out: a set of 17 multistakeholder workshops across 17 European countries run as part of the SHAPE ENERGY (Social sciences \& Humanities for Advancing Policy in European Energy) project between November 2017 and June 2018. A core part of the project's work was to explore on-the-ground challenges facing those working in practical energy initiatives, including at a local policy level, and how Social Sciences \& Humanities insights could help address these. The workshop data offers insight of direct relevance to the problems outlined above: (1) each workshop was designed around (tangibly identified) local energy policy challenges; (2) of the 17 workshops, 14 had direct local authority involvement (in some cases as co-hosts); (3) the methodology was 'scaledup', as in it had to be implemented by those who may not have been already familiar with it, and with clear boundaries, over the time/resource which could go into it; (4) it was therefore used in policy contexts where this type of interactive workshop was far from the norm.

This paper, therefore, aims to contribute to the conversation about why and how those in local energy policy facing roles might use storytelling methods in practical terms when looking to work across stakeholder groups. We contrast what the literature states about the potential of storytelling for solving complex challenges and facilitating collaborative learning processes to what we learnt from actually using storytelling in a wide range of local/regional energy policy contexts.

After a brief introduction on local energy policy challenges and the importance of collaboration, this paper examines bodies of work looking at multi-stakeholder 
participation processes and explore what this means for using storytelling for local policy action (Section 2). Then, this paper introduces the 17 city workshops organized to tackle local energy-related challenges, both in terms of their design methodologies and their content descriptions (Section 3). The paper continues by presenting the results (Section 4) of the storytelling at the workshops, with a particular focus on how storytelling as a methodology is performed in practice, compared to what the theory promises. The paper then discusses (Section 5) some practical considerations for how local authorities or municipalities can go about using storytelling meaningfully in their work. The summary and conclusions (Section 6) give an overview of key insights before discussing in what ways the workshop outcomes may have been influenced by the use of storytelling (as opposed to other workshop methods), as well as how individual and collaborative storytelling methods were found to complement each other.

\section{City Background and Literature Review Sections}

\subsection{Local (energy) policy and the importance of collaboration}

Contemporary urban challenges are characterised by increasing complexity and uncertainty: climate change, rapid urbanization and environmental pollution are just a few [32,33]. These threads cannot be treated in isolation: they are interwoven and require an integrated, cross-disciplinary approach, above all when it comes to producing policy [34-36].

Collaboration among different forms of knowledge is increasingly advocated as needed to create participatory roadmaps for policy action [37-39] and vital for legitimacy and success $[28,40]$. Therefore, several research fields are looking at the challenge of public engagement, local policies, and citizens' participation including energy geographies [41,42], applied ethnography [43], spatial environmental management [44], conflict resolution [45], energy policy [28,46,47].

Local policy actors - including municipalities, local authorities or city agencies - are entities involved in transdisciplinary processes of collaboration and multi-stakeholder inclusion at a city level $[48,49]$. Such groups were identified in the Pact of Amsterdam as 'hotspots' for activating new policies and programs; however, in practice, they still experience numerous difficulties in performing urban policy translations.

The increase in practical skills, competencies, knowledge and organisational learning needed to nurture, foster and activate innovation in the urban policy-making process has been identified as reasons for this difficulty in performing urban policy translation [50,51]. Also, some of the usual tools used in public meetings, educational workshops, and planning processes are arguably insufficient at times to create visions for the future, increase community support and hopefully broaden the original scope of the problem set to be solved [52]. These tools include decision support systems using e.g. Multicriteria Decision Analysis, Argumentation Maps, Participatory-GIS, and Multicriteria Spatial Decision Support System. While they have been used by local policy groups to help resolve conflicts between competing stakeholders [53-55], they have been often insufficient to address the challenge of collaborative governance. As 
explained by [56], tension can also exist between generating concern and awareness, on the one hand, and placing unrealistic expectations among shareholders about the enactment of their plan, on the other.

To this end, the 'narrative turn' of collaborative tools in the policy arena reflects a recognised need for collecting other kinds of data in collaborative workshops. In this regard, qualitative data methods may be better placed to display new insights, misconceptions, beliefs, experiences, or perspectives emerge [57] than the technological devices or mediated visual experiences the earlier named decision support systems may rely on. Narrative-based tools used include, for example, participatory action research and narrative inquiry. These tools are used to discuss the many distinctions in values, expectations, and attitudes, as well as the emotional aspects [58].

In this context, storytelling has emerged as a "potentially important device in helping people from different disciplines, and different domains better understand the world and each other in working on applied environmental problems, including by using the story world to walk outside normal constraints" [23].

\subsection{The promises of storytelling}

In this section, we outline four key dimensions which were explicitly identified ahead of data collection at the workshops as being advantages of using a storytelling technique. These dimensions were identified based on an extensive literature review, as well as informed by significant previous experience with this methodology for behavioural change and multi-stakeholder processes $[59,60]$ which formed the basis for the methodological set-up [61] of the SHAPE ENERGY activities across Europe.

\subsubsection{How storytelling supports learning, unlearning and seeing things differently}

Stories have the potential to contribute to a non-threatening and comfortable exchange of perspectives, and especially learning because the structures underpinning stories are similar across the world and therefore recognizable and familiar ways of transferring and understanding knowledge [62,63]. Storytelling can help facilitate 'unlearning' of individual, sectoral or disciplinary perspectives and ways of knowing which are taken for granted and are often no longer even 'front of mind', but which have become implicit frames of mind [64]. Other collaborative processes, especially those which focus on building consensus and identifying 'solutions' too early, may not always provide such opportunities to unlearn one's position and appreciate the importance of other voices and perspectives.

An essential element of unlearning is the appreciation that bias is perfectly acceptable in stories and that it is a good entry point to understand the perspective another individual holds [59]. Bias is a natural result of the fact that any storyteller has a specific social position and access to specific information [65]. By being explicit about bias and 'allowing' it, storytelling as a workshop methodology can create an atmosphere where participants appreciate and learn how all knowledge is situated and context-dependent [66]; this can result in participants discussing interests, mandates, restrictions, needs, opportunities, risks etc. as part of a collaborative approach built 
around trying to learn about what underpins a specific perspective $[60,67,68]$. There are, of course, (cultural and moral) boundaries as to how much understanding a story can receive, and thus the storytelling approach can work best in groups that to some extent share a basic normative framework.

\subsubsection{How storytelling supports empathy and overcomes conflict}

A second significant promise of storytelling for our workshops was the creation of empathy. Empathy is key to learning because of the level playing field and equality of perspectives it generates, for when we listen to stories, we do so as human beings, not members of a professional environment, sector, class etc. [69]. [69], when discussing collaborative storytelling, argues that "[in] working together to create a mutually acknowledged/accepted truth, the storytellers increase their understanding of each other. This fact makes narrative transactions a useful tool for encouraging social reflection and producing mutual understanding and potentially, social cohesion". Thus, stories can create shared meaning and consequently overcome disciplinary, sectoral or social conflict by creating empathy [70,71]. However, a caveat must be made that research has conversely explored how narrative approaches can in some cases reinforce polarized or stereotyped positions, and thus close down opportunities for dialogue, fueled by true, untrue, or partially true stories $[72,73]$.

\subsubsection{How storytelling supports inclusion and participation}

Inclusiveness was the third crucial condition for our workshops. We wanted everyone to be capable and able to participate in the deliberative process. Stories are something everyone can be expected to have grown up with; consequently, they represent a potentially easy way to share knowledge compared to other forms such as (scientific) reports, for example. Everybody can tell a story. As such, stories can allow people, perspectives and voices to take part that might otherwise not feel competent or able to join the debate [7].

\subsubsection{How storytelling supports collective agenda-setting for local policy action}

Local policy agendas ultimately require commonly defined desirable future visions and collective agenda-setting. Stories, especially those based on individual (end-user) perspectives, are valuable material to construct desirable and legitimate futures on [74], and to reflect on the impact of different (also more radical alternative) futures in the life of an individual [75]. Furthermore, Diedrich et al. (2011) state that, if well designed, storytelling can form the foundation for inclusive and participatory future thinking or visioning exercises, including lists of future actions, descriptions of settings, and a chain of past and future actions connected in a way that makes sense.

The use of storytelling to create shared visions and goals and to explore potential futures is not new and has been used as part of scenario planning workshops and to facilitate capacity building in public deliberative spaces, and as part of policy settings, for example in Australia and Vietnam [62,76,77]. Creating future stories is also a known valuable method to organize collaborative visioning processes, but also to enable and coordinate joint action [15]; [78,79]. Collaborative storytelling (also called 'persuasive storytelling') is a particularly powerful approach for activism and for 
generating collective and shared action around a collaborative agenda [80-82]; it is often widely used also to improve planning and policymaking $[26,83,84]$.

The logical consequence of the fact that storytelling allows and explicitly invites multiple voices and perspectives is that the outcomes of the deliberative process, be it an agenda, program or scenario, are by default more commonly defined and consequently more legitimized politically $[85,86]$.

\subsection{Research question}

The theory then is that storytelling can result in learning and unlearning, the creation of empathy and a conflict solving attitude, allow for the inclusion of diverse perspectives, and contribute to the creation of new collaborations and actions. In the following sections of this paper, after discussing the methodology used to set-up our workshops we explore how meaningful the actual application of storytelling specifically in local energy policy contexts can be.

Our research question was, therefore:

- How do the theoretical strengths of storytelling for supporting local policy processes play out in practice?

As part of exploring this question, we also examined what local energy policy issues may be better highlighted (and which others may be backgrounded) through the use of storytelling methods

\section{$3 \quad$ Methodology}

\subsection{Set-up of the multi-stakeholder workshop programme}

The main objective of the 17 city workshops was to tackle local energy-related challenges, in particular those faced by city (and in some cases national) level policymakers. The workshop organizers brought together a broad group of stakeholders relevant to policy processes, including business, non-governmental organizations, representatives from civil society, academia, citizens, private research groups and consultants to discuss these challenges and provide input to the policy process. In eight cases, the workshops were organized in close cooperation with municipalities or local authorities (UK-Cambridge, Norway-Trondheim, The Netherlands-Utrecht, FranceLyon, Serbia-Belgrade, Germany-Heidelberg, Bulgaria-Sofia, Belgium-Brussels); in six instances, with energy or environmental agencies, institutes or companies (LatviaRiga, Portugal-Lisbon, Italy-Turin, Macedonia-Skopje, Turkey-Ankara, RomaniaBrasov); and in three instances, with universities or research organisations (SpainGranada, Moldavia-Chisinau, Czech Republic-Zlin). We note that the SHAPE ENERGY partners who led each workshop also included local universities in 7 cases. Workshops involved between 13 and 32 participants each and 405 in total across all 17; 
details of the $170+$ participating organizations can be found in [87] and are summed up in Table 1.

Table 1- Overview of the SHAPE ENERGY city workshops, in date order. A fuller version, which includes detail on which project partner-led each workshop, is given on pp.8-9 in (Robison et al., 2018).

\begin{tabular}{|c|c|c|c|c|}
\hline City (Country) & Date & $\begin{array}{l}\text { Supporting local } \\
\text { organization } \\
\text { type }\end{array}$ & $\begin{array}{l}\text { No. } \\
\text { participants }\end{array}$ & Topic \\
\hline Riga (Latvia) & 10 Nov 2017 & $\begin{array}{l}\text { Environment } \\
\text { agency or } \\
\text { company }\end{array}$ & 17 & $\begin{array}{l}\text { Challenges and solutions for the } \\
\text { refurbishment of multi-apartment } \\
\text { buildings }\end{array}$ \\
\hline $\begin{array}{l}\text { Cambridge } \\
\text { (UK) }\end{array}$ & 14 Nov 2017 & Municipality & 29 & $\begin{array}{l}\text { Zero Carbon Cambridge: } \\
\text { achieving low energy housing via } \\
\text { multistakeholder collaboration }\end{array}$ \\
\hline Turin (Italy) & 1 Dec 2017 & $\begin{array}{ll}\text { Environment } & \\
\text { agency } & \text { or } \\
\text { company } & \end{array}$ & 25 & $\begin{array}{l}\text { Decentralisation of renewable } \\
\text { energy production and } \\
\text { transmission for the Turin } \\
\text { metropolitan area }\end{array}$ \\
\hline $\begin{array}{l}\text { Brussels } \\
\text { (Belgium) }\end{array}$ & 30 Jan 2018 & Municipality & 18 & $\begin{array}{l}\text { How to support citizen initiatives } \\
\text { in the field of energy at the local } \\
\text { level }\end{array}$ \\
\hline $\begin{array}{l}\text { Trondheim } \\
\text { (Norway) }\end{array}$ & 15 Feb 2018 & Municipality & 28 & $\begin{array}{l}\text { Decarbonisation of Trondheim's } \\
\text { transportation sector }\end{array}$ \\
\hline $\begin{array}{l}\text { Heidelberg } \\
\text { (Germany) }\end{array}$ & 20 Feb 2018 & University & 23 & $\begin{array}{l}\text { The 'energy citizen' and } \\
\text { 'prosumer' - indispensable or } \\
\text { unattainable? }\end{array}$ \\
\hline $\begin{array}{l}\text { Lisbon } \\
\text { (Portugal) }\end{array}$ & $22 \mathrm{Feb} 2018$ & $\begin{array}{ll}\text { Environment } \\
\text { agency } \\
\text { company }\end{array}$ & 32 & $\begin{array}{l}\text { Innovative financial instruments } \\
\text { to support energy efficiency in } \\
\text { urban residential building } \\
\text { refurbishment }\end{array}$ \\
\hline $\begin{array}{l}\text { Belgrade } \\
\text { (Serbia) }\end{array}$ & 27 Feb 2018 & Municipality & 26 & $\begin{array}{l}\text { The sustainable transition of } \\
\text { district heating systems in Serbia }\end{array}$ \\
\hline $\begin{array}{l}\text { Brasov } \\
\text { (Romania) }\end{array}$ & 2 Mar 2018 & $\begin{array}{l}\text { Environment } \\
\text { agency or } \\
\text { company }\end{array}$ & 22 & $\begin{array}{l}\text { Sustainable regional transport- } \\
\text { challenges and solutions }\end{array}$ \\
\hline $\begin{array}{l}\text { Granada } \\
\text { (Spain) }\end{array}$ & 5 Mar 2018 & University & 24 & $\begin{array}{l}\text { A multi-stakeholder approach to } \\
\text { energy poverty }\end{array}$ \\
\hline $\begin{array}{l}\text { Ankara } \\
\text { (Turkey) }\end{array}$ & 15 Mar 2018 & $\begin{array}{l}\text { Environment } \\
\text { agency or } \\
\text { company }\end{array}$ & 31 & $\begin{array}{l}\text { Energy efficiency and building } \\
\text { insulation policy }\end{array}$ \\
\hline $\begin{array}{l}\text { Skopje } \\
\text { (Macedonia) }\end{array}$ & 15 Mar 2018 & $\begin{array}{l}\text { Environment } \\
\text { agency or } \\
\text { company }\end{array}$ & 19 & $\begin{array}{l}\text { The role of energy efficiency in } \\
\text { the reduction of air pollution }\end{array}$ \\
\hline
\end{tabular}




\begin{tabular}{|l|l|l|l|l|}
\hline $\begin{array}{l}\text { Chisinau } \\
\text { (Moldova) }\end{array}$ & 20 Mar 2018 & $\begin{array}{l}\text { Research } \\
\text { Organization }\end{array}$ & 23 & $\begin{array}{l}\text { Challenges for the future of the } \\
\text { Chisinau heating system }\end{array}$ \\
\hline $\begin{array}{l}\text { Grand Lyon } \\
\text { (France) }\end{array}$ & 20 Mar 2018 & Municipality & 13 & $\begin{array}{l}\text { How to approach energy in a } \\
\text { transversal way from the } \\
\text { perspective of the Grand Lyon } \\
\text { local authority }\end{array}$ \\
\hline $\begin{array}{l}\text { Utrecht } \\
\text { (Netherlands) }\end{array}$ & 24 Apr 2018 & Municipality & 30 & $\begin{array}{l}\text { Sustainable renovation of } \\
\text { housing property owned by } \\
\text { landlords }\end{array}$ \\
\hline $\begin{array}{l}\text { Zlin (Czech } \\
\text { Republic) }\end{array}$ & 23 May 2018 & $\begin{array}{l}\text { University (lead } \\
\text { organizer) }\end{array}$ & 26 & $\begin{array}{l}\text { Zlin region energy strategy } \\
\text { visions 2030 }\end{array}$ \\
\hline Sofia (Bulgaria) & 22 Jun 2018 & Municipality & 20 & $\begin{array}{l}\text { Do Renewable Energy Sources } \\
\text { damage or support the security of } \\
\text { energy supply? }\end{array}$ \\
& & & 405 & \\
\cline { 2 - 5 } & TOTAL & &
\end{tabular}

As highlighted earlier, the use of storytelling in the complex context of city-scale political 'hot topics' is an under-explored implementation, and was new to most if not all of the workshops' supporting organisations. Their involvement directly informed the choice of (energy policy-related) workshop topics, as well as assisting with the recruitment of relevant stakeholders, and in some cases, they acted as speakers or facilitators at the workshop.

\subsection{The flexible design of individual workshop agendas}

This was a large scale roll-out of storytelling, and part of this involved the innovative design and testing of methods to train those who would deliver the workshops. All SHAPE ENERGY partners running workshops attended a two-day training event in September 2017, which was accompanied by an internal facilitation guide with templates prepared by storytelling lead Duneworks (with support from Anglia Ruskin University) - this detailed set of guidelines [61] is available open access at the SHAPE ENERGY website. Although some preparation had taken place before the training event, given the first workshops took place in Nov 2017, the detailed planning using this guidance was possible within about 2-3 months. We describe in brief some key features here.

Following 'setting the scene' activities, the workshops were structured on the five stages that [88] identify when undertaking an exchange through storytelling: story finding; storytelling, story expanding, story processing and, finally, story reconstructing (see Table 2). In the methodological guidelines described above, an indicative program was provided, with suggested small group storytelling activities and time slots. These included individual storytelling related to current issues (denoted 
Activity A in Table 2), individual storytelling related to future visions (Activity B), before collaborative storytelling related to future visions (Activity $\mathrm{C}$ ). Having understood the intended 'journey' for participants, it was then up to the local organizers to decide the best combination of activities, based on their assessment of the local circumstances and context. For example, some workshops included more traditional presentations alongside storytelling activities. The workshops each lasted between a half and a full day.

Table 2 - Scheme of the workshops' example storytelling activities, with related storytelling stage, and aims.

\begin{tabular}{|c|c|c|}
\hline $\begin{array}{lr}\begin{array}{l}\text { Storytelling } \\
\text { adapted }\end{array} & \begin{array}{r}\text { stage, } \\
\text { from }\end{array} \\
\text { Alterio } & \text { and } \\
\text { McDrury } & \\
\end{array}$ & Example activities & Aims \\
\hline $\begin{array}{l}\text { 0. } \begin{array}{l}\text { Setting the } \\
\text { scene }\end{array}\end{array}$ & $\begin{array}{l}\text { Icebreaker activity } \\
\text { Stories read by facilitators } \\
\text { Introductory presentations }\end{array}$ & $\begin{array}{l}\text { Creating a safe atmosphere with } \\
\text { participants in a listening mode, not } \\
\text { focused on right or wrong but on } \\
\text { understanding other voices. Allow } \\
\text { participants to feel comfortable to } \\
\text { perform storytelling, as this may be very } \\
\text { new in a professional setting. }\end{array}$ \\
\hline $\begin{array}{ll}\text { 1. } & \begin{array}{l}\text { Story } \\
\text { finding }\end{array} \\
\text { 2. } & \text { Storytelling }\end{array}$ & $\begin{array}{l}\text { Activity A. Writing individual } \\
\text { 'here and now' stories (following } \\
\text { given story spine) } \\
\text { Reading out stories in small } \\
\text { groups and taking notes } \\
\text { about/discussing fundamental issues } \\
\text { heard }\end{array}$ & $\begin{array}{l}\text { Inviting diversity from individual } \\
\text { perspectives. } \\
\text { To frame perspectives and discuss } \\
\text { specific problems, goals and needs. } \\
\text { Selecting the most important issues to } \\
\text { be addressed in more detail in Activities } \\
\text { B/C. }\end{array}$ \\
\hline $\begin{array}{ll}\text { 3. } & \begin{array}{l}\text { Story } \\
\text { expanding }\end{array} \\
\text { 4. } & \begin{array}{l}\text { Story } \\
\text { processing }\end{array} \\
5 . & \text { Story } \\
& \text { reconstructi } \\
\text { ng }\end{array}$ & $\begin{array}{l}\text { Activity B. Writing individual } \\
\text { future stories (using a new story } \\
\text { spine) building from issues identified } \\
\text { in the previous round } \\
\text { Reading out stories and } \\
\text { discussing problems and solutions in } \\
\text { small groups } \\
\text { Activity C. Writing a } \\
\text { collaborative future story (using } \\
\text { similar story spine to B), each } \\
\text { individual adding a sentence to the } \\
\text { previous sentence, thus literally } \\
\text { writing their voice into the collective } \\
\text { story. }\end{array}$ & $\begin{array}{l}\text { Collaboratively constructing a } \\
\text { desirable future and common agenda. } \\
\text { In many cases, this involved working } \\
\text { collaboratively to create an outlook at the } \\
\text { city level for how to tackle the problems } \\
\text { identified over the next } 10-20 \text { years. } \\
\text { Collectively identifying and } \\
\text { discussing commonalities and or } \\
\text { diverging views as to how to solve a } \\
\text { problem. }\end{array}$ \\
\hline
\end{tabular}


Before the workshop, organisers also needed to construct relevant 'story spines' for each of their storytelling activities. A story spine, in this case, is simply a set of beginnings of sentences, which participants could complete in their own words to build a story (see Figure 1), either individually or in turns to create a collaborative story. The story spines used in the workshop were aimed at facilitating learning. Considering we aimed ultimately for some alignment of multiple perspectives and collaboratively creating future agendas, we used a journey story structure for Activity A, which focuses on the learning process without the inherent conflict in hero and villain stories, and with a focus on realistic events (in contrast to most children's stories).

Finally, in the planning stage, workshop leads had to be mindful of the positions of participants within their organisations, and consider potentially hindering hierarchical or pre-existing professional relationships to - as far as possible - create a level playing field within the small groups, each of which was facilitated by a member of the organizing team.

\section{Our Future City Story}

To respond to .... [issue from earlier session]

the following understandings were needed...

.. and, between 2018 and 2022, the following new or pilot projects were run...

However, problems/conflicts arose, for example...

And particular groups worked to address these by...

Ultimately, in working toward the zero-carbon Cambridge 2050 target, the outcome of this work was...

Figure 1- Simple story spine example for Activity $C$ (collaborative future-focussed story) from the Cambridge workshop. The 'issue/s' were identified through group discussion before this activity

\subsection{How participants were introduced to storytelling}

As well as setting out the overall aims of the event, workshops included a short introduction on the why and what of storytelling about SHAPE ENERGY. This included a short brief on how all voices would be equal and those discussions would not focus on whether or not something is 'true', i.e. the discussions would not be about fact-finding, but about highlighting values and norms. The aim this was to allow all the voices to provide input to the debate and collaboratively generate impact and a vision/agenda. Workshop leads also ran through SHAPE ENERGY ethics procedures, including how data would be used and that data could be withdrawn following the 
event, and asking all participants to be respectful of each other, and what was shared. All workshops included the use of a sign-in sheet which explained how data from the event would be used in future outputs and asked for participants' written consent.

As discussed in subsections 2.2.1, 2.2.2, 2.2.3, once performed, collaborative storytelling can be transformational. However, attendees need to be willing to participate in the process. In the workshops we aimed to make people feel comfortable for example by (i) explaining why storytelling had been chosen as a tool; (ii) showing that information shared will be dealt with carefully; (ii) seeing that everyone participates. One suggested way of achieving this was by the facilitators presenting their own individual stories during events.

Importantly, although we present all the results using the English translations collected from workshop leads, workshops were held in the local language in all but one case (the Riga workshop being facilitated in English, which all participants were fluent in); this was seen as particularly important to facilitate the telling of the 'stories'.

\subsection{Analysis process}

The workshops resulted in several data sources: formal reports delivered by each workshop organizer detailing how the workshop went, and how the storytelling methodology had worked in practice; feedback from participants related to the use of storytelling methods; the actual stories were written by participants (a selection of which were translated into English from each workshop). Data quotes included in this paper are from the reports written by workshop organizers.

For the present paper, we firstly systematically analyzed the reports by searching for the following keywords: learning, unlearning, empathy, diversity, inclusion, perspectives, collaboration, agendas. We focused on these words to draw out explicit comments from moderators and workshop participants. Secondly, we undertook a deductive thematic analysis by reading the full workshop report texts to draw out additional data of explicit or implicit relevance to those issues. As an example, the Dutch and Norwegian workshops reported about stories written from the perspective of an 'absent' stakeholder: this illustrates one way in which storytelling invites a diversity of perspectives and empathy.

The feedback from the workshop participants and organizers was also analyzed to provide insight on whether/how storytelling in the workshops contributed to discussing specific topics which may be less likely to emerge or be highlighted in other contexts / via other methodologies. In the workshop reports, a section explicitly referred to the experience of the facilitators/organizer in the use of storytelling, where this material was used to reflect on the research questions of this paper.

Finally, in their reports workshop organizers also were asked to provide tips and recommendations for other workshop organizers, and these sections were used to reflect on the use of storytelling across different contexts, and by different types of moderators. We explicitly searched for keywords such as context, setting, difficulties, negative, and positive to focus on the lessons to be learnt in applying storytelling. Also, we based our analysis on personal experience as moderators and facilitators at the workshops in Cambridge (UK), Utrecht (NL), Granada (SP) and Turin (IT) - which of course led to 
greater familiarity with the delivery and outcomes of these four events - and formal and informal discussions with partners delivering the other workshops.

\section{Results and discussion: storytelling theory versus practice at the workshops}

In this section, we explore the actual application of storytelling in local energy policy contexts. We, therefore, assess how the four theoretical promises of storytelling for supporting local policy processes (as discussed in subsection 2.2) played out in practice.

\subsection{Learning, unlearning and seeing things differently}

The use of storytelling in the workshops was aimed at creating an environment where learning and unlearning could take place, on an individual and a collective level. To begin to achieve this, participants were often asked early on to write a story about the 'here and now' challenges of relevance to the workshop topic from their professional perspective and then read them out to identify the critical issues brought forth in their own and others' stories (Activity A). In practical terms, having people read out their stories brought some challenges in terms of time constraints (or occasionally feeling laboured); we especially note that many participants wanted to further elaborate on what they had written when reading out loud. While the importance of time management had been flagged at the SHAPE ENERGY storytelling training event and should be borne in mind by those seeking to use similar methods, this does demonstrate there was generally a high interest and engagement with storytelling from the start.

Nevertheless, the writing of individual stories and, crucially, reading them out loud proved essential in terms of (un)learning, because it allowed everyone to frame the discussion more earnestly and to feel emotional and intuitive connections to others. It also meant all participants had spoken meaningfully early on in the event, before having to take 'positions' on possible solutions. In our workshops, participants repeatedly reported that a positive atmosphere resulted from the individual storytelling activities. This finding complements MacDonald's three-stage model [89] which acknowledges how positive emotions can emerge from unlearning. As highlighted in the literature by [90], storytelling, joking and making humorous comments, and dialogic methods, in general, can all contribute to trust-building, which can be carried forward into future group activities.

Theoretically, we reflected earlier that storytelling is a non-threatening means of (un)learning about our own and others' perspectives, especially when there is time to do this before solutions are sought. Nevertheless, unlearning is difficult to achieve and observe, precisely because it requires bringing into focus views which we take for granted. As written by [91], "acknowledging that there is a tacit, taken-for-granted dimension to everything we know highlights why unlearning is so difficult: we need to unlearn practices and mental frames that we don't even realize we rely on but which shape our whole perspective. Rational arguments are thus insufficient to accomplish change; an emotional or intuitive element is also needed to convince us at our level of tacit understanding. Stories can be effective in achieving this". 
Thus, whilst the desire participants had to elaborate on their own individual stories hints at an emphasis on individuals perpetuating their own mental frames, we found there to be one clear area of significant (un)learning, and seeing things differently, that the storytelling workshops offered. This was regarding the relationships between stakeholders, and linked power dynamics. The participants at the workshops were representatives of administrations, companies, groups, cities and academic researchers who work on local energy policy issues. Sometimes, these representatives knew each other already very well, and clear hierarchies or other power relations existed; in other cases, participants had not met before. In cases where the relationships and feeling of trust or mistrust were not yet visible for the organizers or participants, the use of storytelling, and especially the individual stories, proved influential in making them visible. In the individual stories, barriers were flagged as fundamental causes of misunderstanding and complicated converging policy processes. Fears and values behind positions of stakeholders became more apparent, and the discussions that followed fell into the relational aspects of the energy issue locally at stake and helped to deepen the local authorities' understanding of those issues. The storytelling methodology could deal with these potential relational challenges in several ways: in Sofia, for example, the workshop involved several senior figures, many of whom knew each other well. To alleviate the existing power-relations effect, the activities were adapted, with less focus on the individual's experience, their own 'stories' about the here and now, and, instead, a greater focus on the potential future through the collaborative elaboration of participants' visions, challenges, and recommendations.

In the Brussels workshop, for instance, the focus was on citizens initiatives for energy saving. Before the workshop, the main challenge appeared to be citizens' burnout. In the workshop, however, power structures deemed unfair were identified. The participants from the citizens' initiatives highlighted that local authorities made insufficient use of input and knowledge from citizens projects and initiatives, which caused them to feel excluded. A similar outcome was found in Riga, where participants fed back to the local authorities that they provided insufficient options for citizens to participate in sessions organized by the administration. Therefore we find that storytelling can be an effective on-the-ground method for facilitating (un)learning about stakeholder relationships in local policy contexts.

\subsection{Empathy and overcoming conflict}

As highlighted, the individual storytelling (Activities $\mathrm{A} / \mathrm{B}$ ) generally created a cordial, inspiring atmosphere for dialogue. In several places, empathy was invited through these individual exercises, with participants even figuratively speaking stepped into other people's shoes. In Trondheim, for example, one participant decided to adapt the exercise: "I have no problems in my daily life, so I will envision that I am my mother and she needs to drive all across town for work. "In Ankara, participants chose to relate the story in the form of a conversation between friends, leading to reflections on the number and complexity of issues generated within the group's experience. Participants identified that the sharing of individual stories at the start, with a focus on understanding 
different perspectives, acted as a stepping-stone for conflict, often avoiding lengthy debate on what was just right or just wrong.

In contrast to empathy generation, however, a lack of trust between participants when this occurred - was found to undermine the aim of the storytelling activities, complicating the creation of realistic collaborative future visions and action plans. In Turin, trust issues, the lack of power perceived by institutions, or the lack of willingness to address them, were arguably not sufficiently addressed before the workshop. This seemed to result in future stories revolving around improbable events such as massive health crises due to air pollution; sabotage of the power plants by future revolutionary groups; or dreamlike stories like the one in which a sociologist becomes CEO of an energy utility company.

Indeed, an area which has had less attention in the theoretical storytelling literature - and which we found evidence for - is that fears can play a major role in weakening the effectiveness of storytelling: fear of legal burdens and sanctions among businesses representatives; fear of the complexity, the obduracy and the unpopularity of a change on a long-time span (by local authorities); fear to be cheated or exploited by business companies operating in the energy sector (by citizens); mistrust in technical supervision by auditor company/ESCO company; mistrust in the EU, national and local institutions felt by citizens, NGOs, the business represents. From most of the stories, these fears emerged as the actual underlying energy policy challenges the authorities had to tackle.

When considering conflict solving, the use of collaborative story writing (Activity C) was of particular relevance. Participants did indeed identify this method as a stepping stone for conflict solving: "As result, the participants understood that solution can be identified always if dialogue is used as [a] base." (Chisinau Workshop)

This activity invited participants to write (or verbalize) their views on the way forward, building on previous contributions from others. However, agreement on which issue should be the focus of the story was intended to be set before the collaborative story-writing started, building on the previous activities. This sometimes proved challenging. When this agreement was not possible, instead of facing that conflict headon or resolving it, in some workshops different collaborative stories were written up simultaneously. This reflected the flexible and adaptable form of storytelling we applied, partly to account for local policy contexts. Whilst this certainly to an extent prevented conflicts being 'solved' at the workshops themselves, this possibility of allowing parallel stories to remain enabled inclusion of diversity which otherwise, in processes aimed at having consensus before moving on, would already have disappeared. One might also argue that during processes which do require a single narrative to be agreed upon, conflicts are often simply backgrounded, rather than resolved.

Maybe the most impressive practical strength of storytelling in terms of creating empathy and a conflict-solving attitude was the workshop in Granada about energy poverty. Nobody in the city had been able to gather all these stakeholders at the same table before (including the city council, the local citizens' organization, the security officers, etc.) since they were arguing in media reports and during demonstrations one against the other. After several ice-breaking moments, all stakeholders worked on their stories in small groups made of mixed representatives from academia, administration, 
business and civil society. Soon these stories demonstrated a shared view on the overarching national political issues, and where unfairnesses lie in the current energy system. This brought an awareness of a necessary collaboration at local level between private and public entities to better understand what the real problems are, and the need to apply the learning and unlearning attitudes to find holistic solutions.

Storytelling can therefore, we found, be an effective means for identifying the differences in perspectives and voices, and then building on this to achieve new pathways on local energy policy issues. Recent studies related to management practices have revealed that professionals can de-formalise managerial tools in some cases through storytelling in order to share knowledge informally with each other $[64,92]$. However, when dealing with a policy context, some have argued that a drive to encourage better trained storytellers, as a means of facilitating and integrating different expertise, may "be a hard sell unless we link this training strongly to a meaningful discussion of the ethics of policy advice" [93]. The Granada workshop demonstrated however how the use of storytelling, allowing individual voices to all have a podium, and all to be heard and taken into account as equal perspectives contributes to restarting a discussion that had become too politically sensitive and contributes to creating a shared sense of ownership for solving the issue among all stakeholders.

The Cambridge workshop highlighted a further valuable contribution of the storytelling set-up in a policy context, which was observed by the local authority cohost. Giving a platform to so many perspectives (and co-hosting the event with nonlocal government partners) helped reduce the tendency to look to the local authority alone when addressing the issues being raised. Thus, these sessions were not just seen as an opportunity to question and criticize the local authority. Instead, all participants tried to contribute constructively to the discussions. Nevertheless, at this same workshop during the brainstorming sessions, there was a tendency by some participants to point at other (non-present) stakeholders as holding significant responsible, rather than focussing on the responsibilities of those in the room, as also found in the literature about storytelling and land recuperation conflicts [94,95].

\subsection{Inclusion and participation}

The third strength of storytelling that we aimed to test in the workshops was ensuring the inclusion and participation of different voices. This was particularly prioritized during the preparation of the workshops which explicitly aimed to invite multiple perspectives to the workshop.

In very conflict-laden cases, such as the Dutch Utrecht case, the fact that the methodology of storytelling would allow each and every perspective to be heard and taken into account and the explicit focus on dialogue, and not so much debating about wrong or right, was crucial in convincing participants to take part prior to the event. This identified strength of creating inclusion was further evidenced in practice. Explicitly inviting multiple perspectives to write their story during the workshop, and giving equal time to each participant to be heard, was crucial to create a sense of value and inclusion. Participants did express being valued for their opinion because of that. The most illustrative example of the strength of creating inclusion with storytelling 
comes from the Utrecht workshop, where one perspective was not physically present that day. Storytelling allowed other participants nevertheless to write a story from their perspective: “...Eventually, participants saw the storytelling method as a means of allowing each participant to talk about their perspective and treating all participants equally. At one table, the participants even took up the role of the landlord to have their arguments in the discussion. The conversations and discussions were focused and intense."

However, storytelling can also complicate participation because of its innovative nature. Some participants felt hesitant or even cynical about writing stories or did not feel creative enough to write a story or found it just difficult.

Some workshop organisers were apprehensive as to whether their stakeholder groups would go along with the activities. Hindering factors were: the context of the workshop (sometimes too formal); the cultural background and the traditions of a country not favourable to engaging everybody in interactive workshops; hierarchical structures among participants who felt shy to try out a 'playful' methodology. In the Heidelberg workshop, "feedback was mixed, because several participants did not recognize enough 'story telling' elements in the prepared templates and therefore rather reported instead of telling stories.".

Since inclusivity is only possible when feelings of uneasiness or opposition are addressed, some workshops (e.g. Riga, Belgrade, Cambridge, Sofia) also included more traditional ways of discussing issues and stories with participants, for example starting the workshop with presentations, and only later introducing storytelling exercises, or not making the storytelling methodology mandatory, and allowing for a simple report of each others' ideas. Sometimes, the writing of individual stories worked well and all participated, but issues emerged when the collaborative story writing exercise took place. This was, for example, experienced in Cambridge and the Netherlands. Reflecting on this, facilitators concluded that it was a question of time. If participants met each other for the first time on the day of the workshop, more time should be allocated to be able to delve more deeply into each other's perspectives, to understand their origin, to feel comfortable with one another before feeling able to write a bold, yet realistic, story together. This study argues that personal, individual storytelling can be a bridge between dialogue and discussion by inviting group members to experience dialogic moments amid deliberative conversation. Stories invite dialogic moments because they help group members negotiate the tension of self-other. This negotiation occurs because through telling and responding to personal stories, group members craft their identities and take on others' perspectives [96].

Inclusion and participation within the collaborative storytelling (Activity $\mathrm{C}$ ) were also affected by whether one person took (physical) ownership in writing the collaborative story or had been the one to identify the 'problem' being addressed, creating the risk of this persons' perspective dominated at the expense of others. That is why sometimes the facilitators took on the role of writing the collaborative story, interpreting the different contributions instead of having each participant write their sentences. Besides, even when dialogue was invited, it still proved challenging to create equal inclusion, because sometimes those in hierarchically lower roles (or younger, or female participants) were not equally heard by more dominant roles, often covered by men. 
Issues of inclusion and exclusion are being recognized as moving beyond simply e.g. gender and role, and will likely play an increasingly important part of local policy processes. As one example, Rice and Mundel have drawn on their collaborative work with disability and non-normatively embodied artists and communities to point at the challenges of negotiating what 'access' and 'inclusion' can mean without erasing the specificities of differentially-lived experiences [97].

\subsection{Collective agenda setting for local policy action}

The last theoretical strength of storytelling, i.e. facilitating the set-up of collaborative actions to take forward, was demonstrated to be valid in several workshops, where participants ended up setting up concrete project proposals together. Pilot project plans were imagined, and collaborative multi-stakeholder networks continued working on the local energy issue even after the workshop.

This was particularly evident in the Granada workshop. Although some of the participants had had public disagreements in political debates, they were pleased to have this opportunity to work together on such a relevant topic. They listened to each other, and every stakeholder's point of view was taken into account to construct a collective future story. Participants commented that it was "a very productive event" and that they were thrilled to find such a mix of sectors in the room and such informal and "relaxed" setting (Figure 2 ).

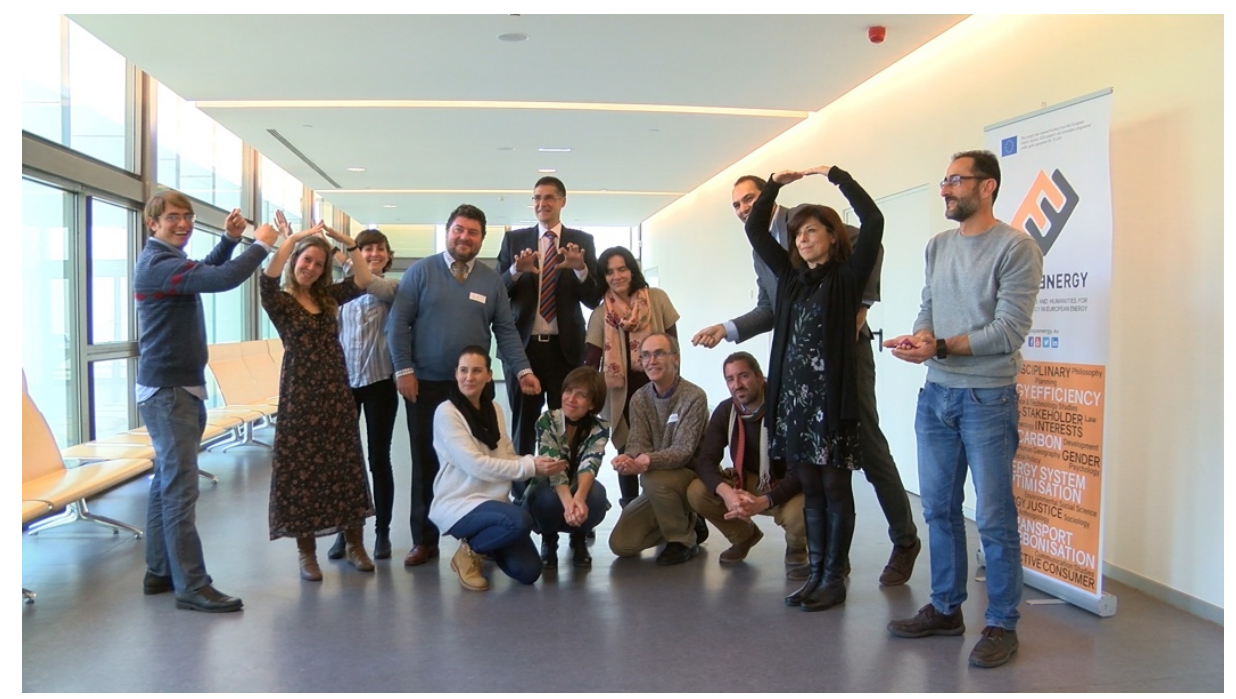

Figure 2 - Impro-theatre techniques used to facilitate the story-telling methodology at the Granada SHAPE ENERGY workshop.

During the final session, and partly also triggered by concrete elements in the story spine about next steps and clear role-taking and the use of 'we' in the sentences given as starting points, there were proposals from some stakeholders to continue the work in future meetings, and somebody even offered their premises as a free meeting point. The 
proposal to create a permanent working group on the energy poverty issue in Granada, including all stakeholders present in the workshop, is developing and begins to take shape at the time of writing this paper. The awareness of the need for educational activities connected to the local energy challenge (in schools, neighbourhood associations, university courses and intersectoral training) is one of the issues that emerged as crucial, and that is currently the focus of the association ('Granada4energy') that sprang out from the workshop itself as a permanent platform to tackle the local energy poverty challenge.

The workshops were organized with co-hosting or supporting organisations. We can therefore reflect here on how the storytelling process led to 'movements' in the positions of these co-organisers. In Riga, the value of such multi-stakeholder meeting was publicly recognized; this led the Riga Energy Agency to create a permanent local platform for the stakeholders to re-propose multiple workshops as follow-ups of the one organized by the SHAPE ENERGY consortium. In Brussels, a follow-up workshop was organized. Other workshop facilitators reported that in-depth analyses from the stories would be a valuable input to national policy processes. For example, in Zlin “...the stories of the key participants (which have been already sent) were beneficial, complex and relevant. These stories were subsequently reported to the authorities of the Zlin region as useful sources for creating Zlin region energy strategy visions 2030."

Indeed, for the local policy actors directly involved in supporting the workshops looking to develop collective agendas, the stories collected in the workshops provided - at a minimum - an excellent opportunity to get direct access to rich end-user perspectives on the issues being discussed, and their needs. In Ankara, storytelling helped to understand the complexity of local energy policy issues concerning building insulation from the end-user perspective. For instance, some practices aimed at improving energy efficiency can impact other aspects (such as health). In Brasov, there was significant agreement on "the important role of civil society in pushing the decision-makers towards actions". In Riga, end-user perspectives were discussed as the main challenge for the implementation of building retrofitting solutions - such as mistrust in institutions (fear of corruption, doubts over the quality of building work) and greater value on 'cosmetic work' than energy saving. These were seen as giving serious justification for developing a communication and dissemination strategy before any other activity. In Lisbon, both householder and city-level issues such as increasing housing prices (renting and selling), the loss of population because of tourism pressure and gentrification, complex condominium legislation and heavy regulations related to cultural and architectural heritage for refurbishment processes also made the municipality more aware of the need of a holistic communication strategy before putting together a decision-making process. As such storytelling can undoubtedly have the added value of improving local policymaking processes, as outlined in Skopje: "The workshop was organized in a way to allow participants to have a longer elaboration of their views regarding the air pollution. Every participant had their "5 minutes" of unstopped discussion. The workshop allowed for improvement into the local process by exchanging the new valuable information between the local authorities and citizen organizations...". 
The workshops took place within their local context, history and web of prior organizational relationships; we also observed therefore that the potential for future collaborations did depend on whether participants were already working together on that issue and if they had the feeling of being able to influence it. In Lyon, for example, this was not the case, and although participants started with standard problem definition, they did not feel able to change anything and dropped the efforts to elaborate on further scenarios.

\section{$5 \quad$ Practical considerations for storytelling in local policy processes}

Given that the theoretical strengths of storytelling have indeed been (partially) validated in the practice of our workshops we hope that this research can be of value to local policy actors. This section, therefore, discusses five key considerations local authorities or municipalities may need to take to meaningfully apply storytelling in their work, especially when they may not already be familiar with such methodologies when there are limitations on the time/resources, where this type of interactive workshop is somewhat alien within some political contexts, and where potential participants have hectic schedules and may not immediately see the added value of such approaches. While in section 4 we illustrated how the theoretical strengths of storytelling played out on the ground, we now note the following specific learnings about when these may not be achieved:

1) Time is key to the success of the storytelling methodology. Not only at the workshop itself, to allow participants enough space to write, and especially to read their story out loud, but also to prepare the workshop. Since the topic was often conflictladen and controversial, much time could go into informing participants about the basic intention of the workshops as not being focused on acquiring consensus but to create a different type of dialogue, where all voices receive equal attention.

2) An accurate stakeholder profile scan was also essential in identifying how far the invitees might be open to storytelling or feel reluctant. Depending on the assessment of the organizers, the invitations varied in how much they provided information about storytelling or explicitly refrained from doing so not to scare off participants. Also, this pre-assessment resulted sometimes in a different set-up of the workshop; for example, including more traditional presentations instead of jumping into storytelling directly, to ensure the workshop participants would feel at ease and safe.

3) Several workshop organizers did a dry run of segments of their workshop, both in terms of content and format, thus practising the moderation roles, but also to identify potential upfront conflicts that might arise between stakeholders, time issues, and make sure the moderators for the different tables would all follow the same set-up.

4) A key finding was that training in moderation skills (or hiring a professional facilitator where training is not possible), proved essential to ensure a smooth environment for the storytelling use and the overall workshop efficacy. Moderators that made sure all voices were heard and received equal attention were essential in creating a sense of safety amongst stakeholders, especially less represented voices. 
5) Another critical aspect for local energy policymakers is to be aware of how far storytelling allows for real actionable outcomes. Since the workshops were aimed at the inclusion of multiple perspectives, the actions coming out of the storytelling activities were also multi-stakeholder initiatives (or the start of conversations around these) and did not always include a local authority as a player for a feasible action plan.

Despite these requirements for the effective use of storytelling in tackling local energy policy challenges, such approaches proved valuable for local policymakers including for the wealth of "social" material on certain topics collected during a workshop. This included a diverse set of perspectives, both as personal and collaborative stories, and notes taken during the discussions. This material can be gathered to feed into local policy processes understanding actual constraints not easily capturable from quantitative queries and structured interviews, although the analysis of such amount of qualitative data needs adequate time and resources to be achieved.

Finally, many workshops did see the start of new coalitions, rebooting processes that had become stuck in debates about perspectives, knowledge, and expertise is relevant, right or wrong. New ideas for collaborations emerged. If local authorities continue facilitating these emerging collaborations after such 'academic-originated' workshops, those can be a starting point for a much longer multi-stakeholder process on the local policy level.

\section{$6 \quad$ Summary and conclusions}

Current EU energy policy targets bring challenges in their actual implementation on the ground. To explore how meaningful the application of storytelling in local energy policy contexts can be, we sought to explore how the theoretical strengths of storytelling for supporting local policy processes play out in practice. Key insights are given in Table 3. In this brief concluding section we draw on these insights to reflect on two overarching themes: firstly how central was storytelling itself (as opposed to other facilitated, discussion-based qualitative methods) was to the outcomes achieved, and secondly, the way individual and collaborative storytelling methods complement or contrast with each other. Finally, we mention some of the potential analysis from the rich data from these 17 workshops that there was no scope to explore for in this paper.

Table 3 - The four theoretical promises of storytelling we identified, and key insights from the 17 workshops. 


\begin{tabular}{|c|c|}
\hline Theoretical promise & Key insights \\
\hline $\begin{array}{l}\text { Learning, } \\
\text { unlearning } \\
\text { and seeing } \\
\text { things } \\
\text { differently }\end{array}$ & $\begin{array}{l}\text { - Early sharing of stories built a positive, non-threatening } \\
\text { atmosphere } \\
\text { - Participants desire to elaborate their own stories hints at } \\
\text { perpetuating own frames } \\
\text { - However, an area of significant (un)learning was } \\
\text { regarding the relationships between stakeholders } \\
\text { - This led policy actors to have greater clarity on power } \\
\text { structures, especially where these were deemed unfair }\end{array}$ \\
\hline $\begin{array}{l}\text { Empathy and } \\
\text { overcoming conflict }\end{array}$ & $\begin{array}{l}\text { - Stories allowed participants to step into others' shoes } \\
\text { - Lack of trust and fears can undermine storytelling } \\
\text { activities, e.g. leading to unrealistic future visions } \\
\text { - Allowing parallel stories enabled diversity which, in } \\
\text { processes aimed at consensus, would have disappeared } \\
\text { - Giving a platform to many perspectives helped reduce the } \\
\text { tendency to look to local policy actors alone when } \\
\text { addressing issues }\end{array}$ \\
\hline $\begin{array}{l}\text { Inclusion and } \\
\text { participation }\end{array}$ & $\begin{array}{l}\text { - The aim of allowing every perspective to be heard was } \\
\text { crucial in convincing some participants to attend } \\
\text { - Storytelling also allowed participants to write from } \\
\text { missing stakeholders' perspectives } \\
\text { - Some participants, in some contexts, felt hesitant or even } \\
\text { cynical about writing stories } \\
\text { - Participants need sufficient time to delve into each other's } \\
\text { perspectives, before feeling capable to write a bold, yet } \\
\text { realistic, collaborative story } \\
\text { - Inclusion was affected by whether one person took } \\
\text { (physical) ownership in writing the collaborative story or } \\
\text { each person could write their sentences into the story. }\end{array}$ \\
\hline $\begin{array}{l}\text { Collective agenda } \\
\text { setting for local } \\
\text { policy action }\end{array}$ & $\begin{array}{l}\text { - Elements in the story spine about next steps and the use of } \\
\text { 'we' in sentences, led to proposals for concrete future } \\
\text { initiatives } \\
\text { - Policy actor co-organisers recognized benefits such as the } \\
\text { creation of more permanent platforms, feeding into local } \\
\text { strategy visions, and providing rich evidence of stakeholder } \\
\text { perspectives } \\
\text { - The potential for future collaborations depended in part } \\
\text { on prior organizational relationships } \\
\text {-Although in some cases where collaboration had come to } \\
\text { a grinding halt, the storytelling exercise reopened the } \\
\text { dialogue and initiated renewed collaboration as well }\end{array}$ \\
\hline
\end{tabular}


We consider here whether the collaborative project plans and other workshop outputs generated could have been achieved by other means; there are many such contenders for alternative facilitated, discussion-based, workshop methods, as well as different ways of applying storytelling itself. For example, in an influential study [98], developing collaborative plans were found to be successful through applying a roleplay simulation as a method of interaction and bricolage as a mode of collective reasoning. In this way, they found: "scenario building and storytelling can make collective sense of complexity, of predicting possibilities in an uncertain world, and can allow the playful imagination, which people normally suppress, to go to work. In the course of engaging in various roles, participants develop identities for themselves and others and become more effective participants, representing their stakeholders' interests more clearly."

From Table 3 we can identify that when the SHAPE ENERGY methodology proved particularly effective, there were six areas which were linked to the use of stories rather than other techniques. These were: (i) the speed at which stories facilitate a nonthreatening atmosphere in which everyone speaks; (ii) enabling significant (un)learning regarding the relationships between stakeholders with the stories highlighting the implementation context and (power) issues as they played out on the ground; (iii) the way stories allowed participants to step into others' shoes and write from missing stakeholders' perspectives; (iv) our flexible storytelling approach of allowing parallel stories enabling diversity which, in processes aimed at consensus, would have disappeared; (v) storytelling being successful in convincing some participants to attend since every view was to be listened to; (vi) elements in the story spine about next steps and the use of 'we' in sentences, led not only to proposals for concrete future initiatives but also to new and or renewed collaboration.

However, the effectiveness of storytelling does depend on its alignment with the aims of organisers, and indeed of participants in attending such events. If there is sufficient mutual investment in deliberative approaches, and organisers and participants feel sufficiently open to writing stories, it can be highly successful. Allowing for a mix of more traditional approaches and storytelling methods can also create a sense of comfort amongst the participants. Furthermore, flexibility in the actual use of the storytelling methodology is vital, tailoring it to the local needs. After all, storytelling is a means to facilitate more inclusive deliberative local policy processes, not a goal in itself.

We also feel it is worth exploring how collaborative storytelling can build effectively on individual storytelling, as we assess that the combination of the two was important in achieving the more inclusive deliberative process aimed for. To reach a shared collaboration practice, stakeholders need a certain degree of intersubjectivity (i.e., common aims, care and cognitive task-related procedures), which can be taken for granted (e.g., between two adults belonging to the same organization), negotiated, or obtained through fine-tuning among them [99]. Being able to build on each other's ideas, participants enjoyed the shared understanding of their collaborative product, as has been found in the literature about grounding and problem-solving in multimodal 
computer-mediated collaboration [100] or about structuring children's narrative competence [101].

This combination of individual storytelling - which helped to build this intersubjectivity - before moving on to collaborative storytelling generally proved useful in facilitating the negotiation needed for creating collaborative visions of a desirable future, balancing perspectives, costs, benefits, roles and responsibilities of those scenarios. The method of collaboratively writing a story can be a particularly effective method to not only invite collective reasoning, but allowing for each participant to literally have a voice in that collective story, having written sentences themselves, building on the other's sentences, finishing each other's sentences, not criticizing previous sentences, but incorporating them in their story. A clear finding is that moderation is vital in terms of making sure that all perspectives are taken into account in the final collaborative story writing, and that expert or specialist views are not dominant. In the most successful cases, this process can help to renew collaborations that have become problematic. It was this last part of collaboratively working towards a 'we' and actionable story about the future that renewed energy for collaboration in for example Utrecht and Granada.

The data from the workshops was very rich, and the scope of this paper did not allow us to explore in-depth many other worthwhile lines of investigation. For example, in this paper, we provided a birds-eye view across the workshop findings, but we did not zoom into just a few cases to provide a more in-depth analysis of for example changing perspectives of stakeholders, as witnessed in how their individual contemporary story and their future story incorporated elements of other individual stories they listened to. Another line of research would be a more longitudinal approach to workshop outcomes. As highlighted in section 5, time is key to the success of the storytelling methodology and this includes the potential to allocate time to undertake a proper follow-up. In the SHAPE ENERGY project, there was no dedicated resource for a systematic review of all the local policy actions which stemmed from the storytelling workshops in the months following, and whilst commitments were indicated at the time, we have not always been informed about the impacts on the actual implementation of local policy target actions. This is an explicit limitation of this study and a clear line of future research for storytelling experiments on the local policy level. However, the intrinsic characteristics of storytelling as an innovative and playful methodology can undoubtedly be a valuable additional tool for achieving learning, conflict solving and inclusion in local energy policy contexts. The materials to come out of the workshops can now be used in diverse ways by city administrations, those working in all aspects of energy, as well as Social Science and Humanities researchers in terms of food for thought for future research. 


\section{References}

[1] F.F. Nerini, J. Tomei, L.S. To, I. Bisaga, P. Parikh, M. Black, A. Borrion, C. Spataru, V.C. Broto, G. Anandarajah, B. Milligan, Mapping synergies and trade-offs between energy and the Sustainable Development Goals, Nat. Energy. 3 (2018). https://doi.org/10.1038/s41560-017-0036-5.

[2] P. Fragkos, N. Tasios, L. Paroussos, P. Capros, S. Tsani, Energy system impacts and policy implications of the European Intended Nationally Determined Contribution and low-carbon pathway to 2050, Energy Policy. 100 (2017) 216-226.

[3] Y. Lu, N. Nakicenovic, M. Visbeck, A.-S. Stevance, Policy: Five priorities for the UN sustainable development goals, Nat. News. 520 (2015) 432.

[4] J. Fitzgerald, J. Wolak, The roots of trust in local government in western Europe, Int. Polit. Sci. Rev. 37 (2016) 130-146.

[5] UN General Assembly, Transforminng our world: the 2030 Agenda for Sustainable Development, 2015. https://doi.org/10.1007/s13398-014-01737.2.

[6] C. Morton, C. Wilson, J. Anable, The diffusion of domestic energy efficiency policies: A spatial perspective, Energy Policy. 114 (2018) 77-88.

[7] A.M. Levenda, J. Richter, T. Miller, E. Fisher, Regional sociotechnical imaginaries and the governance of energy innovations, Futures. 109 (2019) 181-191.

[8] C.A. Miller, J. Richter, J. O’Leary, Socio-energy systems design: a policy framework for energy transitions, Energy Res. Soc. Sci. 6 (2015) 29-40.

[9] G. Sonetti, O. Arrobbio, P. Lombardi, I.M. Lami, S. Monaci, “'Only Social Scientists Laughed": Reflections on Social Sciences and Humanities Integration in European Energy Projects, Energy Res. Soc. Sci. 61 (2020) 101342. https://doi.org/10.1016/J.ERSS.2019.101342.

[10] S. Heidenreich, W. Throndsen, R. Sari, G. Sonetti, M. Ryghaug, T. KernGillard, O. Arrobbio, R. Mourik, A. Nikolaev, Competitive, secure, low-and Technology (Norway) Ramazan Sari, Middle East Technical University (Turkey) European Commission Decision C(2017)2468 of 24, 2017.

[11] C. Foulds, T.H. Christensen, Funding pathways to a low-carbon transition, Nat. Energy. 1 (2016) 1-4.

[12] T. Kitchen, D. Whitney, S. Littlewood, Local Authority/AcademicCollaboration and Local Agenda 21 Policy Processes, J. Environ. Plan. Manag. $40 \quad$ (1997) 645-660. https://doi.org/10.1080/09640569711994.

[13] J. Blake, Overcoming the 'value-action gap'in environmental policy: Tensions between national policy and local experience, Local Environ. 4 (1999) 257278.

[14] A. Sharma, K. Kearins, Interorganizational Collaboration for Regional Sustainability: What Happens When Organizational Representatives Come 
Together?, J. Appl. Behav. Sci. 47 (2010) 168-203. https://doi.org/10.1177/0021886310381782.

[15] A. Diedrich, L. Walter, B. Czarniawska, Boundary stories. Constructing the validation centre in West Sweden, Scand. J. Public Adm. 15 (2011) 3-20.

[16] V.A. Shaffer, E.S. Focella, A. Hathaway, L.D. Scherer, B.J. Zikmund-Fisher, On the Usefulness of Narratives: An Interdisciplinary Review and Theoretical Model, Ann. Behav. Med. 52 (2018) 429-442. https://doi.org/10.1093/abm/kax008.

[17] O. Scharmer, The Essentials of Theory U: Core Principles and Applications, Berrett-Koehler Publishers, 2018.

[18] H. Della Bosca, J. Gillespie, The coal story: Generational coal mining communities and strategies of energy transition in Australia, Energy Policy. $120 \quad$ (2018) 734-740. https://doi.org/https://doi.org/10.1016/j.enpol.2018.04.032.

[19] S. Barr, A. Gilg, G. Shaw, 'Helping People Make Better Choices': Exploring the behaviour change agenda for environmental sustainability, Appl. Geogr. 31 (2011) 712-720. https://doi.org/http://dx.doi.org/10.1016/j.apgeog.2010.12.003.

[20] D.H. Llewellyn, M. Rohse, R. Day, H. Fyfe, Evolving energy landscapes in the South Wales Valleys: Exploring community perception and participation, $\begin{array}{lllll}\text { Energy } & \text { Policy. } & 108 & \text { (2017) } & \text { 818-828. }\end{array}$ https://doi.org/https://doi.org/10.1016/j.enpol.2017.04.028.

[21] B.K. Sovacool, What are we doing here? Analyzing fifteen years of energy scholarship and proposing a social science research agenda, Energy Res. Soc. Sci. 1 (2014) 1-29. https://doi.org/10.1016/j.erss.2014.02.003.

[22] B.K. Sovacool, S.E. Ryan, P.C. Stern, K. Janda, G. Rochlin, D. Spreng, M.J. Pasqualetti, H. Wilhite, L. Lutzenhiser, Integrating social science in energy research, Energy Res. Soc. Sci. 6 (2015) 95-99. https://doi.org/10.1016/j.erss.2014.12.005.

[23] M. Moezzi, K.B. Janda, S. Rotmann, Using stories, narratives, and storytelling in energy and climate change research, Energy Res. Soc. Sci. 31 (2017) 1-10. https://doi.org/10.1016/j.erss.2017.06.034.

[24] B. Goodchild, A. Ambrose, A. Maye-Banbury, Storytelling as oral history: revealing the changing experience of home heating in England, Energy Res. Soc. Sci. 31 (2017) 137-144.

[25] G. Sherriff, T. Moore, S. Berry, A. Ambrose, B. Goodchild, A. Maye-Banbury, Coping with extremes, creating comfort: User experiences of 'lowenergy'homes in Australia, Energy Res. Soc. Sci. 51 (2019) 44-54.

[26] K.B. Janda, M. Topouzi, Closing the loop: Using hero stories and learning stories to remake energy policy, Rethink. Renew, Restart, Proc. ECEEE Summer Study, Belambra Les Criques, Toulon/Hyères, Fr. (2013) 3-8.

[27] S. Owens, L. Driffill, How to change attitudes and behaviours in the context of energy, Energy Policy. 36 (2008) 4412-4418.

[28] G. Comodi, L. Cioccolanti, F. Polonara, C. Brandoni, Local authorities in the context of energy and climate policy, Energy Policy. 51 (2012) 737-748. 
https://doi.org/10.1016/j.enpol.2012.09.019.

[29] Y.-C. Kim, S.J. Ball-Rokeach, Community Storytelling Network, Neighborhood Context, and Civic Engagement: a Multilevel Approach, Hum. Commun. Res. 32 (2006) 411-439. https://doi.org/10.1111/j.14682958.2006.00282.x.

[30] I. Andersson, 'Green cities' going greener? Local environmental policymaking and place branding in the 'Greenest City in Europe,' Eur. Plan. Stud. 24 (2016) 1197-1215. https://doi.org/10.1080/09654313.2016.1152233.

[31] A. Leipprand, C. Flachsland, M. Pahle, Advocates or cartographers? Scientific advisors and the narratives of German energy transition, Energy Policy. 102 (2017) 222-236. https://doi.org/https://doi.org/10.1016/j.enpol.2016.12.021.

[32] R. Kemp, D. Loorbach, J. Rotmans, Transition management as a model for managing processes of co-evolution towards sustainable development, Int. J. Sustain. Dev. World Ecol. 14 (2007) 78-91.

[33] D. Loorbach, Transition management: new mode of governance for sustainable development, International books, Utrecht, 2007.

[34] D.J. Lang, A. Wiek, M. Bergmann, M. Stauffacher, P. Martens, P. Moll, M. Swilling, C.J. Thomas, Transdisciplinary research in sustainability science: practice, principles, and challenges, Sustain. Sci. 7 (2012) 25-43.

[35] D. Spreng, Transdisciplinary energy research - Reflecting the context, Energy Res. Soc. Sci. 1 (2014) 65-73. https://doi.org/10.1016/j.erss.2014.02.005.

[36] H.E. Aalto, L. Marcus, J. Torsvall, Towards a social-ecological urbanism: Coproducing knowledge through design in the Albano Resilient Campus project in Stockholm, Sustain. 10 (2018). https://doi.org/10.3390/su10030717.

[37] D. Streimikiene, T. Baležentis, I. Kriščiukaitienė, Promoting interactions between local climate change mitigation, sustainable energy development, and rural development policies in Lithuania, Energy Policy. 50 (2012) 699-710. https://doi.org/https://doi.org/10.1016/j.enpol.2012.08.015.

[38] P. Lombardi, E. Trossero, Beyond energy efficiency in evaluating sustainable development in planning and the built environment, Int. J. Sustain. Build. Technol. Urban Dev. 4 (2013) 274-282. https://doi.org/10.1080/2093761X.2013.817360.

[39] G. Bridge, S. Bouzarovski, M. Bradshaw, N. Eyre, Geographies of energy transition: Space, place and the low-carbon economy, Energy Policy. 53 (2013) 331-340.

[40] M. Ratinen, Social embeddedness of policy actors. The failure of consumerowned wind energy in Finland, Energy Policy. 128 (2019) 735-743. https://doi.org/https://doi.org/10.1016/j.enpol.2019.01.004.

[41] L. Gailing, A. Röhring, Is it all about collaborative governance? Alternative ways of understanding the success of energy regions, Util. Policy. 41 (2016) 237-245.

[42] P. Devine-Wright, B. Wiersma, Opening up the "local" to analysis: exploring the spatiality of UK urban decentralised energy initiatives, Local Environ. 18 (2013) 1099-1116.

[43] P.J. Maginn, Towards more effective community participation in urban 
regeneration: the potential of collaborative planning and applied ethnography, Qual. Res. 7 (2007) 25-43.

[44] A. Simao, P.J. Densham, M.M. Haklay, Web-based GIS for collaborative planning and public participation: An application to the strategic planning of wind farm sites, J. Environ. Manage. 90 (2009) 2027-2040.

[45] T. Nabatchi, Putting the "public" back in public values research: Designing participation to identify and respond to values, Public Adm. Rev. 72 (2012) 699-708.

[46] B.R. Upreti, D. van der Horst, National renewable energy policy and local opposition in the UK: the failed development of a biomass electricity plant, Biomass and Bioenergy. 26 (2004) 61-69.

[47] D. Pitt, E. Bassett, Innovation and the Role of Collaborative Planning in Local Clean Energy Policy, Environ. Policy Gov. 24 (2014) 377-390. https://doi.org/10.1002/eet.1653.

[48] C. Foulds, R. Robison, Advancing Energy Policy, Springer, 2018.

[49] C. Foulds, R. Robison, Mobilising the Energy-Related Social Sciences and Humanities, in: Adv. Energy Policy, Springer, 2018: pp. 1-11.

[50] H. Bulkeley, H. Schroeder, K. Janda, J. Zhao, A. Armstrong, S.Y. Chu, S. Ghosh, Cities and climate change: the role of institutions, governance and urban planning, Change. 28 (2009) 30.

[51] N.C. Nagorny-Koring, T. Nochta, Managing urban transitions in theory and practice-The case of the Pioneer Cities and Transition Cities projects, J. Clean. Prod. 175 (2018) 60-69.

[52] B.E. Goldstein, W.H. Butler, Expanding the scope and impact of collaborative planning: combining multi-stakeholder collaboration and communities of practice in a learning network, J. Am. Plan. Assoc. 76 (2010) 238-249.

[53] M. Jelokhani-Niaraki, J. Malczewski, A group multicriteria spatial decision support system for parking site selection problem: A case study, Land Use Policy. 42 (2015) 492-508.

[54] L. Thabrew, A. Wiek, R. Ries, Environmental decision making in multistakeholder contexts: applicability of life cycle thinking in development planning and implementation, J. Clean. Prod. 17 (2009) 67-76.

[55] H. Fünfgeld, Facilitating local climate change adaptation through transnational municipal networks, Curr. Opin. Environ. Sustain. 12 (2015) 67-73.

[56] T.M. Koontz, We Finished the Plan, So Now What? Impacts of Collaborative Stakeholder Participation on Land Use Policy, Policy Stud. J. 33 (2005) 459481. https://doi.org/10.1111/j.1541-0072.2005.00125.x.

[57] P. Atkinson, Narrative turn or blind alley?, Qual. Health Res. 7 (1997) 325344.

[58] G. Kurtz, Integrating a Facebook group and a course website: The effect on participation and perceptions on learning, Am. J. Distance Educ. 28 (2014) 253-263.

[59] R. Mourik, S. Rotmann, The Power of Storytelling, (2015).

[60] S. Rotmann, R. Mourik, B. Goodchild, Once Upon a Time... How to tell a good energy efficiency story that'sticks', in: eceee, 2015. 
[61] R. Mourik, R. Robison, S. Breukers, Storytelling-SHAPE ENERGY facilitation guidelines for interdisciplinary and multi-stakeholder processes, Cambridge: SHAPE ENERGY. (2017).

[62] R. Davies, J. Dart, The 'most significant change'(MSC) technique, A Guid. to Its Use. (2005).

[63] S.L. Star, J.R. Griesemer, Institutional ecology,translations' and boundary objects: Amateurs and professionals in Berkeley's Museum of Vertebrate Zoology, 1907-39, Soc. Stud. Sci. 19 (1989) 387-420.

[64] J.S. Brown, E.S. Gray, The people are the company, Fast Co. 1 (1995) 78-82.

[65] M. Alvesson, K. Sköldberg, Tolkning och reflektion-vetenskapsfilosofi och kvalitativ metod (2: a upplagan), Lund Studentlitteratur. (2008).

[66] S. Jasanoff, (No?) Accounting for expertise, Sci. Public Policy. 30 (2003) $157-$ 162.

[67] F. Hanleybrown, J. Kania, M. Kramer, Channeling change: Making collective impact work, (2012).

[68] P. Sumpf, C. Büscher, P. Claudot, Y. Jeuken, C. Mnich, M. Ruth, N. Ortar, R. Robison, SHAPE ENERGY Reflexive Review of Interdisciplinary Working, (2018).

[69] C. Boase, Digital storytelling for reflection and engagement: A study of the uses and potential of digital storytelling, Retrieved Febr. 12 (2008) 2009.

[70] K. Lindberg, B. Czarniawska, Knotting the action net, or organizing between organizations, Scand. J. Manag. 22 (2006) 292-306.

[71] J.L. Polman, J.M.G. Hope, Science news stories as boundary objects affecting engagement with science, J. Res. Sci. Teach. 51 (2014) 315-341.

[72] M. Andrews, S.D. Sclater, C. Squire, M. Tamboukou, Qualitative Research Practice, (2004). https://doi.org/10.4135/9781848608191.

[73] J.E. Kendall, K.E. Kendall, Storytelling as a Qualitative Method for IS Research: Heralding the Heroic and Echoing the Mythic, Australas. J. Inf. Syst. 17 (2012). https://doi.org/10.3127/ajis.v17i2.697.

[74] L. Goodchild, R. Jonsen, P. Limerick, D. Longanecker, Public policy challenges facing higher education in the American West, Springer, 2014.

[75] M. Wolsink, Planning of renewables schemes: Deliberative and fair decisionmaking on landscape issues instead of reproachful accusations of noncooperation, Energy Policy. 35 (2007) 2692-2704.

[76] H. Selin, S.D. VanDeveer, EU Environmental Policy Making and Implementation: Changing Processes and Mixed Outcomes, in: 2015.

[77] V. Jarva, Introduction to narrative for futures studies, J. Futur. Stud. 18 (2014) $5-26$.

[78] P. Trompette, D. Vinck, Back to the notion of boundary object (2), Rev. d'anthropologie Des Connaissances. 4 (2010) i-m.

[79] D. Vinck, Taking intermediary objects and equipping work into account in the study of engineering practices, Eng. Stud. 3 (2011) 25-44.

[80] J.P. Dimond, M. Dye, D. LaRose, A.S. Bruckman, Hollaback!: the role of storytelling online in a social movement organization, in: Proc. 2013 Conf. Comput. Support. Coop. Work, ACM, 2013: pp. 477-490. 
[81] J.A. Throgmorton, Planning as persuasive storytelling: The rhetorical construction of Chicago's electric future, University of Chicago Press, 1996.

[82] J.A. Throgmorton, Planning as persuasive storytelling about the future: Negotiating an electric power rate settlement in Illinois, J. Plan. Educ. Res. 12 (1992) 17-31.

[83] M. Van Hulst, Storytelling, a model of and a model for planning, Plan. Theory. 11 (2012) 299-318.

[84] J.B. Bushnell, S.P. Holland, J.E. Hughes, C.R. Knittel, Strategic Policy Choice in State-Level Regulation: The EPA's Clean Power Plan, Am. Econ. J. Econ. Policy. 9 (2017) 57-90.

[85] J.-A. Paschen, R. Ison, Narrative research in climate change adaptationExploring a complementary paradigm for research and governance, Res. Policy. 43 (2014) 1083-1092.

[86] J. Carbonell, A. Sánchez-Esguevillas, B. Carro, From data analysis to storytelling in scenario building. A semiotic approach to purpose-dependent writing of stories, Futures. 88 (2017) 15-29.

[87] R. Robison, S. Dupas, R. Mourik, M. Torres, E. Milroy, Europe's local energy challenges: Stories and research priorities from 17 multi-stakeholder city workshops, in: Cambridge SHAPE ENERGY.[Online] Available Https//Shapeenergy. $\quad$ Eu/Wp-Content/Uploads/2018/12/Workshop-KeyFindings. Pdf [Accessed 18 December 2018], 2018.

[88] M. Alterio, J. McDrury, Learning through storytelling in higher education: Using reflection and experience to improve learning, Routledge, 2003.

[89] G. Macdonald, Transformative unlearning: safety, discernment and communities of learning, Nurs. Inq. 9 (2002) 170-178.

[90] N. V Nygren, A. Jokinen, A. Nikula, Unlearning in managing wicked biodiversity problems, Landsc. Urban Plan. 167 (2017) 473-482.

[91] D. Sole, D.G. Wilson, Storytelling in organizations: The power and traps of using stories to share knowledge in organizations, LILA, Harvard, Grad. Sch. Educ. (2002) 1-12.

[92] K. Brownlee, Conversation and Storytelling as Cultural Practices: Designing a Communication Activism Intervention with Migrant English Language Learners, (2018).

[93] L. Topp, D. Mair, L. Smillie, P. Cairney, Knowledge management for policy impact: the case of the European Commission's Joint Research Centre, Palgrave Commun. 4 (2018) 87.

[94] M.E. Meneses, M.C. Castillo-González, Digital storytelling and the dispute over representation in the Ayotzinapa case, Lat. Am. Perspect. 45 (2018) 266283.

[95] A.A. Sanchíz, Land recuperation and conflict on the margins of state formation in northern Chiapas, Identities Glob. Stud. Cult. Power. 15 (2008) 574-606.

[96] L.W. Black, Deliberation, Storytelling, and Dialogic Moments, Commun. Theory. 18 (2008) 93-116. https://doi.org/10.1111/j.1468-2885.2007.00315.x.

[97] C. Rice, I. Mündel, Multimedia storytelling methodology: Notes on access and inclusion in neoliberal times, Can. J. Disabil. Stud. 8 (2019) 118-148. 
[98] J.E. Innes, D.E. Booher, Consensus Building as Role Playing and Bricolage, J. Am. Plan. $\quad$ Assoc. 65 (1999) 9-26. https://doi.org/10.1080/01944369908976031.

[99] A. Devescovi, E. Baumgartner, Joint-reading a picture book: Verbal interaction and narrative skills, Cogn. Instr. 11 (1993) 299-323.

[100] P. Dillenbourg, D. Traum, Sharing solutions: Persistence and grounding in multimodal collaborative problem solving, J. Learn. Sci. 15 (2006) 121-151.

[101] G. Pinto, C. Tarchi, L. Bigozzi, Is two better than one? Comparing children's narrative competence in an individual versus joint storytelling task, Soc. Psychol. Educ. 21 (2018) 91-109. https://doi.org/10.1007/s11218-017-9411-0. 